\title{
Effects of Propagule Phenology (Non-Dormant Versus Dormant) and Planting System (Vertical Versus Horizontal) on Growth Performance of Willow Clones Grown Under Different Weeding Regimes
}

\author{
Monika Welc ${ }^{1}$ (D) Anneli Lundkvist ${ }^{1} \cdot$ Theo Verwijst $^{1}$
}

Published online: 6 July 2018

(C) The Author(s) 2018

\begin{abstract}
To assess the effects of propagule phenology and planting system on growth performance of three willow clones grown under different weeding regimes, a field experiment was performed in central Sweden 2014-2016. Freshly harvested (non-dormant) and cold-stored (dormant) cuttings (planted vertically) and billets (planted horizontally) from willow clones Tordis, Tora, and Jorr were planted in weeded and in unweeded plots. Sprouting was significantly higher for willows grown from non-dormant (74\%) than dormant (58\%) propagules and for cuttings (84\%) compared with billets (42\%). Survival was higher for willows from nondormant propagules in weeded (71\%) compared with unweeded (63\%) plots, willows from dormant propagules in weeded (72\%) compared with unweeded (60\%) plots, and for willows from cuttings (93\%) compared with billets (39\%). During 2014-2016, aboveground biomass production was significantly higher for willows from cuttings $\left(11.71 \mathrm{t} \mathrm{DW} \mathrm{ha}{ }^{-1}\right)$ than from billets $(6.13 \mathrm{t}$ $\left.\mathrm{DW} \mathrm{ha}{ }^{-1}\right)$, grown in weeded $\left(15.29 \mathrm{t} \mathrm{DW} \mathrm{ha}^{-1}\right)$ than in unweeded $\left(2.55 \mathrm{t} \mathrm{DW} \mathrm{ha}^{-1}\right)$ plots, and differed significantly among willow clones $\left(11.48,9.27\right.$, and $6.01 \mathrm{tDW} \mathrm{ha}^{-1}$ for Tordis, Tora, and Jorr, respectively). In this study, (i) planting with cold-stored and freshly harvested willow propagules was equally successful and therefore cold storage could be potentially avoided and replaced with planting of freshly harvested propagules in early spring; however, (ii) in terms of measured growth performance parameters, willows grown from cuttings performed better than grown from billets; and (iii) weed competition significantly reduced survival and aboveground biomass production, confirming that weed control during establishment of willow is crucial.
\end{abstract}

Keywords Billet $\cdot$ Biomass production $\cdot$ Bud burst $\cdot$ Cutting $\cdot$ Horizontal planting $\cdot$ Salix $\cdot$ Short rotation coppice $\cdot$ SRC . Survival $\cdot$ Vertical planting $\cdot$ Weeds

\section{Introduction}

For further implementation of willow short rotation coppice (SRC), it is important to improve the profitability of the cropping system. Prospects for cost reduction regarding major cost components as establishment and harvest are good. In Sweden, willow SRC is commercially established from dormant hardwood cuttings planted vertically in the soil [1]. Cuttings are produced from 1-year-old willow shoots harvested after growth cessation (i.e., late autumn to early winter) and cold-stored until planting (i.e., early to late spring), thereby

Monika Welc

monika.welc@slu.se

1 Department of Crop Production Ecology, Swedish University of Agricultural Sciences, Ulls väg 16, Box 7043, 750

07 Uppsala, Sweden retaining their vigor and vitality [2]. Cold storage is logistically demanding and encompasses approximately $3-5 \%$ of the entire cost of planting material (Lena Åsheim, Salix Europa $\mathrm{AB}$, Sweden, personal communication). By replacing planting with cold-stored cuttings with freshly harvested cuttings, planting costs could be reduced. In Sweden, willow SRC is conventionally established from cuttings that are cut and planted into the soil during the same operation. A willow planter of the type 'Woodpecker 601' [3] or Salix Maskiner 'Step Planter' [4] is commonly used during planting operations. The rental cost of a 'Step Planter' is roughly 1000 SEK $\mathrm{ha}^{-1}$ (Stig Larsson, European Willow Breeding, personal communication), which accounts for approximately $10 \%$ of the total planting costs [5]. Therefore, development of alternative and less expensive planting techniques would be desirable to lower the costs for willow SRC establishment.

To reduce costs of willow SRC establishment while simultaneously maintaining yield levels, alternative 
methods of willow propagule production and planting systems have been tested. In a controlled experiment, Welc et al. [6] showed that non-dormant and dormant willow cuttings presented similar aboveground biomass production and ability to suppress and tolerate weeds. This implies that under the conditions of that study cold storage of cuttings was redundant when willow was planted early in the growing season. McCracken et al. [7] tested two methods of horizontal willow planting and compared them with traditional vertical planting system in a small-scale field experiment. They showed that mortality of billets (planting density $26.000 \mathrm{ha}^{-1}$ ) due to drying accounted for approximately $17 \%$ lower aboveground biomass production as compared with cuttings (planting density $15.000 \mathrm{ha}^{-1}$ ) grown over two harvest cycles (6 years). Edelfeldt et al. [8] assessed the effects of different planting systems on early willow growth performance. Cuttings of varying lengths were planted horizontally at different depths and compared with cuttings planted vertically. They concluded that planting system with longer horizontally planted cuttings $(>50 \mathrm{~cm}$ ) leads to uneven establishment and gaps in the stand and recommended the use of vertically planted cuttings with a length of at least $20 \mathrm{~cm}$. The effect of planting system on long-term yield effect of willow clone Bjørn in Denmark was investigated by Larsen et al. [9]. They found significant differences in yield produced from $0.2 \mathrm{~m}$ cuttings $\left(8.6 \mathrm{Mg} \mathrm{ha}^{-1}\right.$ year $\left.^{-1}\right)$ and $0.1 \mathrm{~m}$ billets $\left(5.6 \mathrm{mg} \mathrm{ha}^{-1}\right.$ year $^{-1}$ ) but only during the first rotation. To decrease willow SRC planting costs by using simpler planting equipment, Gro and Culshaw [10] suggested that willow 'Step Planter' could be replaced by sugarcane planter placing billets horizontally in the soil.

The aim of this study was to quantify growth performance of willow as affected by propagule phenology and planting system. Growth parameters, however, have been shown to be affected by interaction between different factors such as propagule phenology, planting system, weeding regime, and willow clone. Therefore, we compared sprouting, survival, and aboveground biomass production of willows grown from non-dormant and dormant propagules (cuttings and billets) of three willow clones (Tora, Tordis, Jorr) planted vertically (cuttings) and horizontally (billets) in soil with two levels of weed pressure (weeded and unweeded).

We hypothesized that (1) phenological development, in terms of sprouting, (a) will be higher for willows grown from non-dormant propagules compared with dormant ones, (b) will be higher for cuttings than for billets, and (c) will be clone-dependent, and (2) subsequent growth performance (survival and aboveground biomass production) over time will (a) depend on propagule phenology and planting system and (b) will differ between weeding regimes and willow clones.

\section{Materials and Methods}

\section{Experimental Design}

A field experiment was performed during 2014-2016 at Ultuna, near Uppsala, Sweden $\left(59^{\circ} 80^{\prime} \mathrm{N}, 17^{\circ} 65^{\prime} \mathrm{E}\right)$ on a neutral (Ap horizon $\mathrm{pH}_{\mathrm{H} 2 \mathrm{O}}=7.4$ ) Vertic Cambisol with total $\mathrm{C}, \mathrm{N}, \mathrm{P}$, and $\mathrm{K}$ contents of $3.6 \%, 0.31 \%, 247 \mathrm{mg} \mathrm{g}^{-1}$, and $716 \mathrm{mg} \mathrm{g}^{-1}$, respectively. The upper soil layer consisted of glaciofluvial deposits with a clay content of $30-45 \%$ [11]. Monthly mean air temperature was $7.9,7.5$, and $7.0{ }^{\circ} \mathrm{C}$ for years 2014, 2015, and 2016, respectively. Corresponding values for monthly precipitation were 51.9, 46.0, and $36.8 \mathrm{~mm}$ for years 2014,2015 , and 2016, respectively [12].

The field experiment was established on an area of 0.6 ha (Fig. 1). The experiment consisted of four blocks (each with an area of $42 \mathrm{~m} \times 36 \mathrm{~m})$. Each block was then divided into four plots. Each plot $(42 \mathrm{~m} \times 9 \mathrm{~m})$ consisted of three subplots. Each subplot $(14 \mathrm{~m} \times 9 \mathrm{~m})$ consisted of two subsubplots (subplot $7 \mathrm{~m} \times 9 \mathrm{~m}$ ) (Fig. 1a). The blocks represented experimental replications (Fig. 1b). Weeding regime (two levels: weeded, unweeded) was randomized to plots within blocks in such way that two plots were weeded and two were unweeded. The two planting systems (two levels: cutting, billet) were randomized to plots within weeding regime levels. Willow clone (three levels: Tordis, Tora, Jorr) was randomized to the subplots within plots, and propagule phenology (two levels: dormant, non-dormant) was randomized to the subsubplots within each subplot (Fig. 1).

\section{Field Preparation}

In the autumn 2013, the experimental field was sprayed with a tank solution $\left(4.0 \mathrm{~L}^{-1} \mathrm{ha}^{-1}\right)$ of glyphosate (Roundup Bio, Monsanto, Bromma, Sweden) to control weeds. Three weeks later, the field was plowed to a depth of approximately $20 \mathrm{~cm}$. One week before planting (i.e., May 12, 2014), weeds, stones, and remnants of willow stumps from a previous experiment (harvested in 2010, Weih, Nordh [13]) were manually removed from the field. During May 19-23, 2014, willow was manually planted.

\section{Propagule Preparation and Planting}

Three willow clones commercially available and tested in several experiments in Sweden were used in the study: Tora (Salix schwerinii $\times$ Salix viminalis $)$, Tordis $(($ S. viminalis $\times$ S. schwerinii) $\times S$. viminalis) $)$, and Jorr $(S$. viminalis $)[14]$. For each of the willow clones, 225 one-year-old dormant shoots (each approximately $160 \mathrm{~cm}$ in length and with a basal diameter of about $1 \mathrm{~cm}$ ) were randomly harvested from a willow nursery at Pustnäs, Uppsala, Sweden $\left(59^{\circ} 48^{\prime} \mathrm{N}, 17^{\circ}\right.$ $40^{\prime} \mathrm{E}$ ) on March 3, 2014, wrapped in polyethylene bags, and 
Fig. 1 Design of the field experiment at Ultuna, Sweden. a The block is divided into four plots. Each plot (striped area) consists of three subplots. Each subplot (undulated area) consists of two subsubplots (checkered area). b The experiment consists of four blocks (separated by thick black lines). Weeding regime (two levels: weeded, white; unweeded, grey) was randomized to plots within blocks. Planting systems (two levels: cutting, billet; italic fond) were randomized to plots within weeding regime levels. Willow clone (three levels: Tordis, Tora, Jorr; capital font) was randomized to the subplots within plots, and propagule phenology (two levels: dormant, italic bold font; nondormant, italic normal font) was randomized to the subsubplots within each subplot a

b

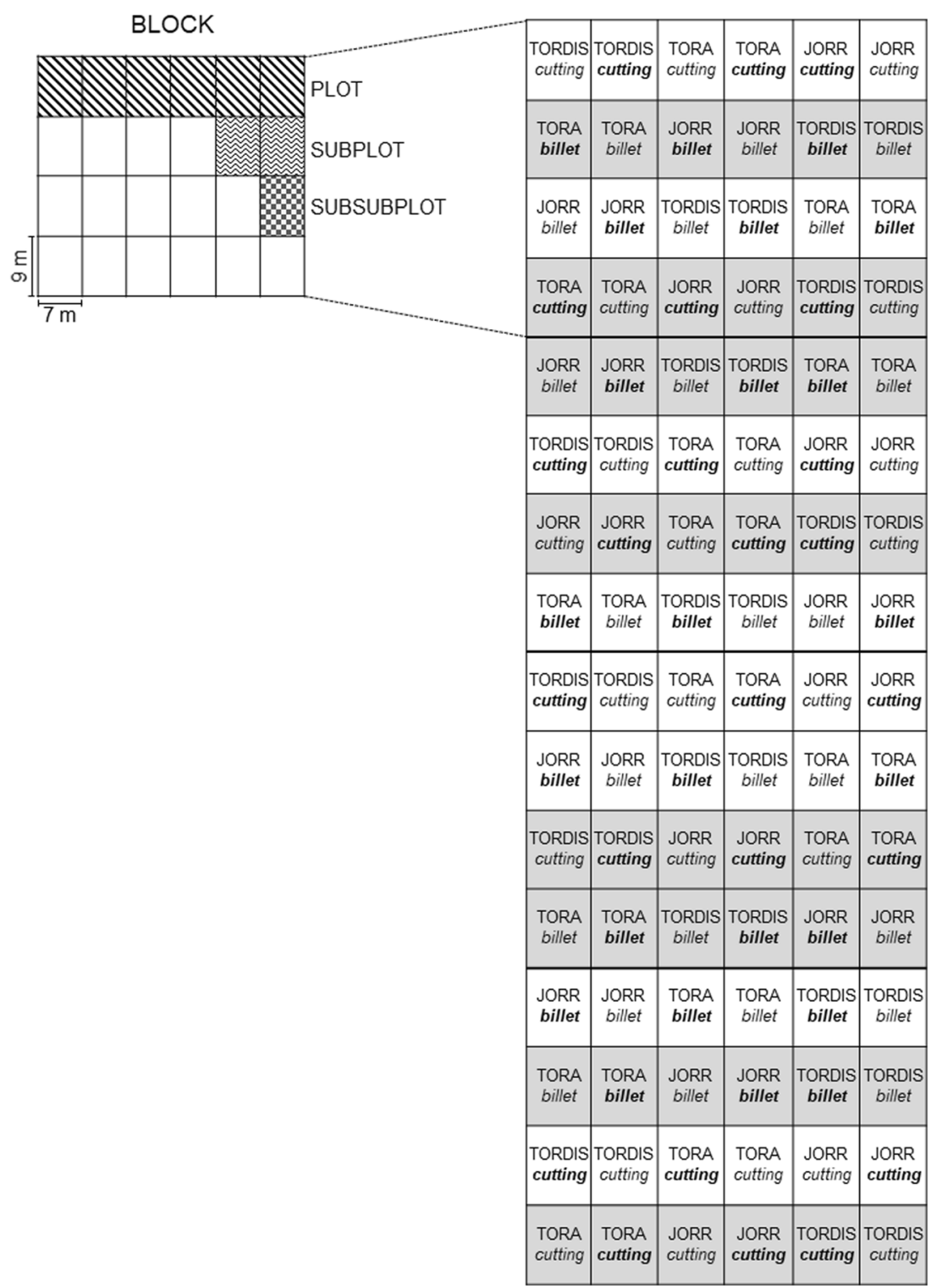

cold-stored (at approximately $-4{ }^{\circ} \mathrm{C}$ ) [2] until planting. From these shoots, dormant cuttings and billets (see details below) were produced. On May 12, 2014, 300 (Tora) and 250 (Tordis and Jorr) 1-year-old shoots were harvested from the same nursery and stored at approximately $+4{ }^{\circ} \mathrm{C}$ until planting. These shoots presented the first signs of dormancy break, i.e., the buds started to open and the shoot tip had a length of 1-4 mm [15]. The non-dormant cuttings and billets were produced from these shoots. From both the apical and basal part of each shoot, a 20-cm-long fragment was removed to obtain more uniform and consistent planting material and to reduce effects of dehydration, fungal or bacterial infections, or storage-caused damages. The remaining fragments of the shoot were cut manually into six cuttings with a length of $20.0 \pm 0.3 \mathrm{~cm}$ or 12 billets with a length of $10.0 \pm 0.3 \mathrm{~cm}$.
The propagules were produced on May 9-14, 2014 and stored in polyethylene bags at approximately $-4{ }^{\circ} \mathrm{C}$ (dormant cuttings and billets) or at approximately $+4{ }^{\circ} \mathrm{C}$ (non-dormant cuttings and billets). One day before planting (i.e., May 18, 2014), both non-dormant and dormant cuttings and billets were stored at approximately $+4{ }^{\circ} \mathrm{C}$ and transferred to room temperature $\left(18-20^{\circ} \mathrm{C}\right)$ about $6 \mathrm{~h}$ before planting.

Cuttings were planted in the soil vertically, leaving $1-2 \mathrm{~cm}$ of the cutting above the soil surface. Billets were planted in the soil horizontally thus placed in trenches at a depth of approximately $3 \mathrm{~cm}$ and covered with the soil. A double row planting system was used, with $150 \mathrm{~cm}$ between double rows, $75 \mathrm{~cm}$ between rows within double rows, and 70 or $35 \mathrm{~cm}$ between individual cuttings and billets, respectively, within the row [1]. This resulted in a nominal density of approximately 13.000 
and 26.000 plants ha ${ }^{-1}$ for cuttings and billets, respectively. In the experiment, a total of 11.520 propagules were planted. To avoid edge effects, one row of willow clone Tora was planted around the field experiment. During the first month after planting, the weather conditions were rather dry, with an accumulated precipitation of approximately $1 \mathrm{~mm}$ [12].

At planting, weeds covered at max. $20 \%$ of the area. In plots designated as weeded, the first manual weeding was performed 21 days after willow planting and then every other week during the growing seasons 2014 (June-September) and 2015 (April-September). In May 2016, the closure of canopy (mainly Tora and Tordis) was recorded in weeded plots, and since this time, weeding was not continued. The field experiment was fertilized with $60 \mathrm{~kg}$ of $\mathrm{N} \mathrm{ha}^{-1}$ (N/P/K 21:4:7, Yara International ASA, Malmö, Sweden) in June 2015 (after first growing season) [16].

\section{Measurements}

To avoid border interactions between willow clones and treatments, sprouting, survival, and aboveground biomass production were assessed in a net plot $(4.5 \mathrm{~m} \times 5.6 \mathrm{~m})$ centrally located in each experimental plot (Fig. 1). Sprouting was assessed at six dates in 2014 (June 2, 6, 13, 16, 26, and 30, 2014). From each block, six subplots were chosen (willow clone, planting system, and propagule phenology; i.e., 24 plots). This was done since it was technically difficult to assess sprouting for all planted propagules. Sprouting should be assessed during a relatively short period of time to minimize misestimation due to delay in time between the assessments between the first and the last propagule. Cuttings were regarded as sprouted when the tip of the most apical bud started to bend from the stem, bud scales started to open and the length of the shoot tip was 1-4 mm, i.e., bud burst developmental stage $2[6,15]$. Billets were regarded as sprouted when the first leaves started to emerge and protrude above the soil surface. At each assessment date, number of sprouted individuals per net plot was calculated. Based on the initial planting density (i.e., 13.000 cuttings ha ${ }^{-1} ; 26.000$ billets per $\mathrm{ha}^{-1}$ ), number of sprouted plants per hectare was estimated.

Survival was assessed at four dates: June 30, 2014; March 2, 2015; March 1, 2016; and December 5, 2016. All cuttings or billets in each net plot (in total 32 cuttings and 64 billets per net plot) were inspected for survival. If no signs of bud development were found above the soil surface (2014) or live tissue under the shoot bark $10 \mathrm{~cm}$ above the ground level (20152016), the willow plant was considered to be dead. Based on the initial planting density, survival per net plot was scaled up to willow survival per hectare and presented as cumulative during the consecutive growing seasons.

Aboveground biomass production was assessed on dormant willows (i.e., before bud burst in the spring or after growth cessation in the winter) at three occasions: March 2,
2015; March 1, 2016; and December 5, 2016. The diameter of each shoot per stool was measured with a digital caliper at about $10 \mathrm{~cm}$ above the ground level. Outside the net plot, 30 shoots per willow clone and weeding regime stratified according to shoot diameter were harvested, and dry weight $\left(80^{\circ} \mathrm{C}\right.$, $72 \mathrm{~h}$ ) of each individual shoot was recorded. The data were used to establish allometric relationships between shoot dry weight (DW) and the diameter $(D)$ :

$\mathrm{DW}=b \times D^{c}$

where $b$ is a constant and $c$ is an exponent [17]. The diameter values from the net plots were used in the allometric equations, obtained as described above, to calculate shoot dry weight per net plot, which was scaled up to dry weight per ton per hectare $\left(\mathrm{t} \mathrm{DW} \mathrm{ha}{ }^{-1}\right)$.

\section{Data Handling and Statistics}

All statistical analyses were performed using PROC MIXED in SAS 9.3 [18]. Linear mixed models were fitted using restricted maximum likelihood (REML) method. To meet the assumption of normally distributed residuals, the data were $\log$ transformed (sprouting) [19] or logit transformed (aboveground biomass production) [20] before statistical analyses. Degrees of freedom were inspected in all performed analyses in order to assess validity of the model used. In the statistical models, assessment date, A [six levels (sprouting), four levels (survival), and three levels (aboveground biomass production)]; weeding regime, W (two levels: weeded, unweeded); propagule phenology, PH (two levels: non-dormant, dormant); planting system, $\mathrm{P}$ (two levels: cutting, billet); willow clone, C (three levels: Tora, Tordis, and Jorr); and block, B (four levels) were considered as fixed effects. Plot (PL), subplot (SP), subsubplot (SSP) were used as random effects. Models used in the study were as follows:

\section{Model 1: Willow Survival and Aboveground Biomass (Full Design)}

The experiment had four B, four PL per block, three SP per plot, and two SSP per SP. [The two P (see Section 2.1 for details) were randomized to PL in such a way that each $\mathrm{B}$ had two PL of each P]. Moreover, C were randomized to SP, and PH to SSP within SP. Within each SSP, assessments were made at six A (sprouting: June 2, 6, 13, 16, 26, and 30, 2014), four A (survival: June 30, 2014; March 2, 2015; March 1, 2016; and December 5, 2016), and three A (aboveground biomass: March 2, 2015; March 1, 2016; and December 5, 2016). Therefore, the experiment was analyzed using a model that included fixed effects of A, $\mathrm{W}, \mathrm{PH}, \mathrm{P}$, and $\mathrm{C}$, fixed effect of $\mathrm{B}$, and random effects of 
PL, SP, and SSP. Using the short-hand notation proposed by Piepho et al. [21], the model can be written:

$A \times W \times \mathrm{PH} \times P \times C+B: \mathrm{PL} / \mathrm{SP} / \mathrm{SSP}$

\section{Model 2: Willow Sprouting}

From each B, six SP were chosen (willow clone $\times$ planting system $\times$ propagule phenology). This was because willow sprouting is a parameter that need to be assessed during relatively short period of time (see Section 2.4 for details) and (preferently) by the same observer (minimized bias in estimation of developmental stages). In the statistical analysis of sprouting, the factor weeding regime was excluded since the weed cover was rather low (20\%) and was considered to have minor effects on sprouting. Model can be written:

$A \times \mathrm{PH} \times P \times C+B: \mathrm{SP} / \mathrm{SPP}$

The impact of main effects on measured parameter was statistically significant at the cutoff of $P<0.05$. All two-, three-, four-way interactions and five-way interaction between fixed effects were tested in the analyses, but only these statistically significant at cutoff of $P<0.20$ [22] were presented (Tables 1 and 3).

\section{Results}

\section{Willow Sprouting}

Selected main effects, two- and three-way interactions, between main effects significantly affected willow sprouting in the field experiment (Table 1). The number of sprouted propagules increased over time and 4 weeks after planting (from June 2 to June 30,2014), and approximately $84 \%$ of initially planted cuttings (i.e., 10.941 from $13.000 \mathrm{ha}^{-1}$ ) and $42 \%$ of initially planted billets (i.e., 10.982 from $26.000 \mathrm{ha}^{-1}$ ) had sprouted (Fig. 2). Non-dormant propagules presented significantly higher (on average, 6.781 plants $\mathrm{ha}^{-1}$ ) sprouting than dormant propagules (on average, 5.184 plants $\mathrm{ha}^{-1}$ ), and overall $74 \%$ of non-dormant and $58 \%$ of the dormant propagules had sprouted in this field experiment. Interaction between planting system and assessment date significantly affected willow sprouting that increased from June 2 to June 30, 2014 from 1.860 to 10.942 cuttings ha ${ }^{-1}$ and from 532 to 10.982 billets ha $^{-1}$. Significantly affected by interaction between propagule phenology and assessment date, sprouting from June 2 to June 30, 2014 increased from 1.660 to 11.627 willows grown from non-dormant propagules per hectare and from 731 to 10.296 willows grown from dormant propagules per hectare. The interactions between assessment date, planting system, and propagule phenology significantly affected willow sprouting. Overall, sprouting from June 2 to June 30, 2014 differed significantly between non-dormant (from 2.347 to $11.844 \mathrm{ha}^{-1}$ ) and dormant (from 1.372 to $\left.10.038 \mathrm{ha}^{-1}\right)$ cuttings $(P=0.0032)$ but not between nondormant (from 974 to $11.411 \mathrm{ha}^{-1}$ ) and dormant (902 to $10.553 \mathrm{ha}^{-1}$ ) billets $(P=0.1296)$ (Fig. 2). Sprouting was significantly affected by the interactions between assessment date, willow clone, and propagule phenology, and on June 30, 2014, sprouting differed significantly for willow clone Tora grown from non-dormant $\left(10.833 \mathrm{ha}^{-1}\right)$ and dormant $\left(8.571 \mathrm{ha}^{-1}\right)$ propagules.

\section{Willow Survival}

Selected main effects and two-way interactions of the main effects affected willow survival in the field experiment. Survival was not significantly affected by propagule phenology or willow clone (Table 2). None of three-, four-, or fiveway interactions between main effects were statistically significant $(P>0.20)$. Survival of initially planted propagules decreased from 72 to $61 \%$ between June 30, 2014 and December 5, 2016 (Fig. 3). Overall, approximately 69 and $54 \%$ of all planted willows survived in weeded plots and unweeded plots, respectively (Fig. 3). Survival was significantly affected by the interaction between weeding regime and planting system, and approximately 91 and $96 \%$ of initially planted cuttings survived in unweeded and weeded plots, respectively. Approximately 48 and $60 \%$ of initially planted billets survived in unweeded and weeded plots, respectively. Survival was significantly affected by the interaction between planting system and assessment date. After three growing seasons, willows grown from cuttings had significantly higher survival ( $93 \%$ of initially planted cuttings) than grown from billets (39\% of initially planted billets).

\section{Willow Aboveground Biomass Production}

Selected main effects, two- and three-way interactions between main effects affected willow aboveground biomass production in the field experiment (Table 3). Willows grown in weeded plots $\left(15.29 \mathrm{tDW} \mathrm{ha}^{-1}\right)$ produced approximately $83 \%$ more aboveground biomass than willows grown in unweeded plots (2.55 t DW ha ${ }^{-1}$ ) (Fig. 4 and Table 4). After three growing seasons, willows grown from cuttings had produced significantly higher aboveground biomass (11.71 t DW ha ${ }^{-1}$ ) than willows grown from billets (6.13 $\left.\mathrm{t} \mathrm{DW} \mathrm{ha}^{-1}\right)$ (Fig. 4). Willow clone Tordis produced, on average, significantly more biomass (11.48 $\left.\mathrm{t} \mathrm{DW} \mathrm{ha}^{-1}\right)$, than willow clones Tora $(9.27 \mathrm{t}$ DW ha ${ }^{-1}$ ) and Jorr (6.01 t DW ha ${ }^{-1}$ ). From March 2, 2015 to December 5, 2016, aboveground biomass increased significantly from 0.29 to $8.92 \mathrm{t} \mathrm{DW} \mathrm{ha}^{-1}$. The interaction between weeding regime and planting system significantly affected 
Table 1 Mixed model analysis of variance of willow sprouting (propagules ha ${ }^{-1}$ ) in the field experiment

\begin{tabular}{|c|c|c|c|c|}
\hline \multirow[t]{2}{*}{ Source of variation } & \multirow[t]{2}{*}{ Numerator $d f$} & \multicolumn{3}{|c|}{ Willow sprouting (propagules $\mathrm{ha}^{-1}$ ) } \\
\hline & & Denominator $d f$ & $F$ value & $\operatorname{Pr}>F$ \\
\hline Planting system $(\mathrm{P})$ & 1 & 5.75 & 0.04 & 0.8556 \\
\hline Willow clone $(\mathrm{C})$ & 2 & 2.76 & 3.02 & 0.2020 \\
\hline Propagule phenology $(\mathrm{PH})$ & 1 & 11.8 & 13.50 & 0.0033 \\
\hline Assessment date (A) & 4 & 80.0 & 6.91 & $<0.0001$ \\
\hline $\mathrm{P} \times \mathrm{C}$ & 2 & 2.56 & 1.71 & 0.3380 \\
\hline $\mathrm{P} \times \mathrm{PH}$ & 1 & 11.8 & 0.74 & 0.4072 \\
\hline $\mathrm{P} \times \mathrm{A}$ & 4 & 80.2 & 7.46 & $<0.0001$ \\
\hline $\mathrm{PH} \times \mathrm{C}$ & 2 & 11.9 & 0.67 & 0.5314 \\
\hline $\mathrm{PH} \times \mathrm{A}$ & 4 & 78.9 & 2.77 & 0.0330 \\
\hline $\mathrm{A} \times \mathrm{C}$ & 8 & 80.5 & 0.71 & 0.6818 \\
\hline $\mathrm{A} \times \mathrm{P} \times \mathrm{PH}$ & 4 & 78.9 & 5.33 & 0.0008 \\
\hline $\mathrm{A} \times \mathrm{C} \times \mathrm{PH}$ & 8 & 79.4 & 3.36 & 0.0023 \\
\hline
\end{tabular}

The main effects and two-way interactions of the main effects were statistically significant at $P<0.05$. Three-way interactions were statistically significant at $P<0.20$ (only tabulated). Four-way interaction was statistically insignificant $(P>0.20)$

willow aboveground biomass production. Weeding increased biomass production for willows grown both from cuttings and billets (Fig. 4 and Table 4). Over time, the ratio aboveground biomass cutting/billet also decreased substantially in weeded plots, while no such trend was observed in the unweeded plots (Table 4). Cuttings produced on average 1.97 and $9.63 \mathrm{t} \mathrm{DW} \mathrm{ha}^{-1}$ in unweeded and weeded plots, respectively. Aboveground biomass production from billets was 0.58 and $5.11 \mathrm{t} \mathrm{DW} \mathrm{ha}^{-1}$ in unweeded and weeded plots, respectively.

Aboveground biomass production was significantly affected by the interaction between weeding regime and willow clone. Biomass production was 1.22 and $7.75 \mathrm{t} \mathrm{DW} \mathrm{ha}^{-1}$ (Tora), 2.14 and $8.97 \mathrm{t} \mathrm{DW} \mathrm{ha}^{-1}$ (Tordis), and 0.47 and $5.38 \mathrm{t} \mathrm{DW} \mathrm{ha}^{-1}$ (Jorr), in unweeded and weeded plots, respectively. The interaction between weeding regime and assessment date significantly affected aboveground biomass production: from March 2, 2015 to December 5, 2016, from 0.17 to $2.55 \mathrm{t} \mathrm{DW} \mathrm{ha}{ }^{-1}$ in unweeded plots and from 0.40 to $15.29 \mathrm{t}$ DW ha ${ }^{-1}$ in weeded plots. Biomass production was significantly affected by the interaction between planting system and assessment date, and it increased during subsequent growing seasons (Fig. 4). On average, willows grown from cuttings produced significantly more $\left(5.80 \mathrm{t} \mathrm{DW} \mathrm{ha}^{-1}\right)$ aboveground
Fig. 2 Sprouting (propagules $\mathrm{ha}^{-1}$ ) of willows grown from nondormant or dormant willow propagules (cuttings or billets) assessed at six different dates. Each point represents mean values with standard error of the mean $( \pm \mathrm{SE})$. Statistical significance $(P<0.05)$ between planting systems (cuttings or billets) or between planting system within each propagule phenology (non-dormant or non-dormant) is indicated by upper or lowercase letters, respectively. Arrows indicate initial planting density of cuttings (13.000 ha $\left.{ }^{-1}\right)$ and billets (26.000 $\mathrm{ha}^{-1}$ )

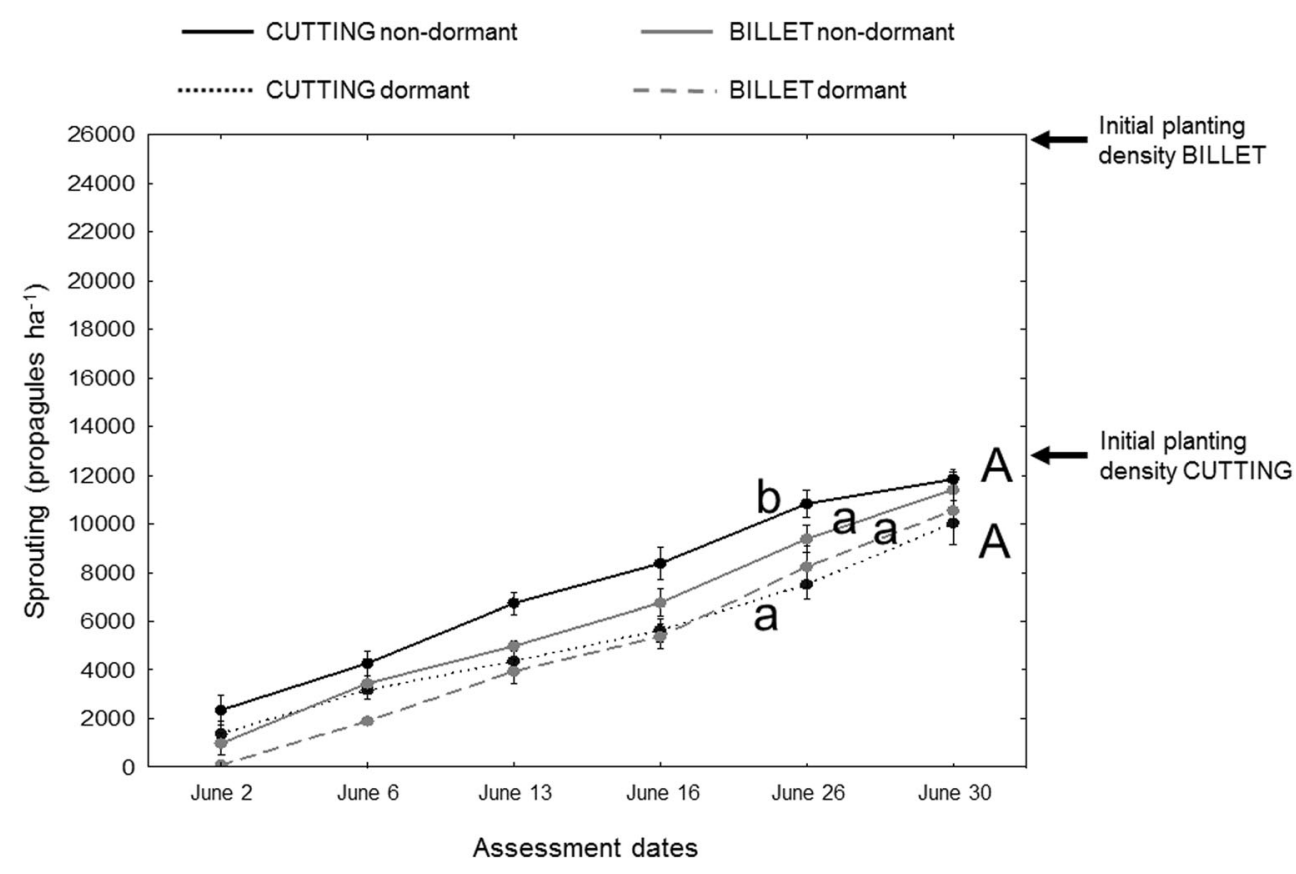


Table 2 Mixed model analysis of variance of willow survival (plants $\mathrm{ha}^{-1}$ ) in the field experiment

\begin{tabular}{lllll}
\hline \multirow{2}{*}{ Source of variation } & Numerator $d f$ & \multicolumn{2}{l}{ Willow survival (plants ha ${ }^{-1}$ ) } & \\
\cline { 4 - 5 } & & Denominator $d f$ & $F$ value & Pr $>F$ \\
\hline Weeding regime (W) & 1 & 12 & 22.99 & 0.0004 \\
Planting system (P) & 1 & 12 & 36.72 & $<0.0001$ \\
Willow clone (C) & 2 & 24 & 2.99 & 0.0691 \\
Propagule phenology (PH) & 1 & 180 & 0.03 & 0.8599 \\
Assessment date (A) & 2 & 180 & 4.96 & 0.0017 \\
W $\times$ P & 1 & 12 & 19.70 & 0.0008 \\
W $\times$ C & 2 & 24 & 1.05 & 0.3654 \\
W $\times$ PH & 1 & 180 & 0.24 & 0.6264 \\
W $\times$ A & 2 & 180 & 2.61 & 0.0765 \\
P $\times$ C & 2 & 24 & 1.71 & 0.2017 \\
P $\times$ PH & 1 & 180 & 1.77 & 0.1849 \\
P $\times$ A & 2 & 180 & 3.80 & 0.0243 \\
C $\times$ PH & 2 & 180 & 0.48 & 0.6166 \\
C $\times$ A & 4 & 180 & 0.75 & 0.5594 \\
A $\times$ PH & 2 & 180 & 0.31 & 0.7349 \\
\hline
\end{tabular}

The main effects and two-way interactions of the main effects were statistically significant at $P<0.05$. None of the three-, four-, or five-way interactions were statistically significant $(P>0.20)$ biomass than willows grown from billets $\left(2.84 \mathrm{tDW} \mathrm{ha}^{-1}\right)$. The interaction between willow clone and assessment date significantly affected aboveground biomass production. From March 2, 2015 to December 5, 2016, biomass production increased from 0.32 to $9.27 \mathrm{t} \mathrm{DW} \mathrm{ha}^{-1}$ for willow clone Tora, from 0.38 to $11.48 \mathrm{t} \mathrm{DW} \mathrm{ha}^{-1}$ for willow clone Tordis, and from 0.16 to $6.01 \mathrm{t} \mathrm{DW} \mathrm{ha}^{-1}$ for willow clone Jorr. Interactions between assessment date, weeding regime, and planting system significantly affected aboveground biomass production. From March 2, 2015 to December 5, 2016, biomass production increased in
WEEDED

CUTTING non-dormant

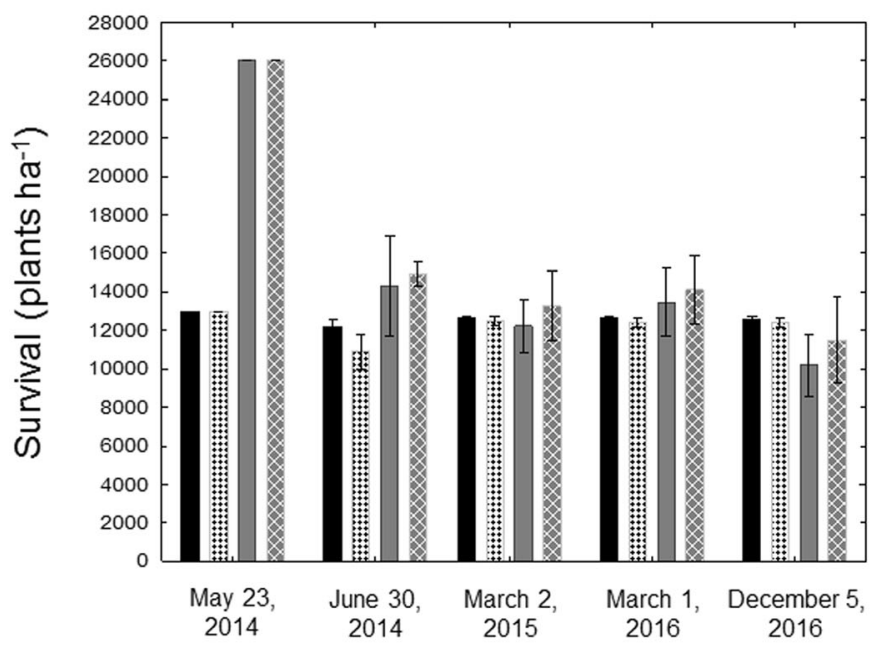

UNWEEDED

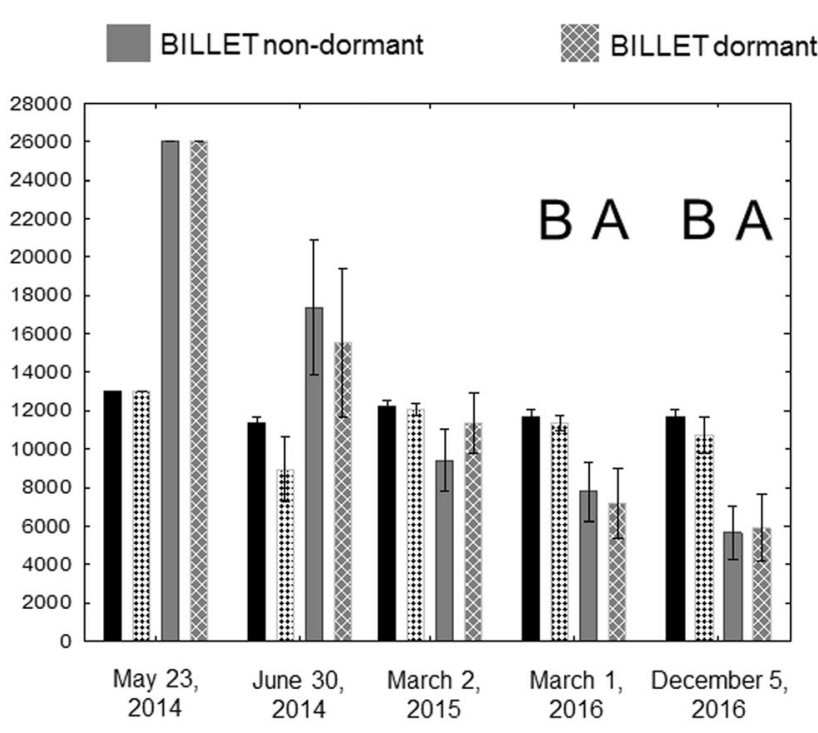

Fig. 3 Survival (plants $\mathrm{ha}^{-1}$ ) for non-dormant or dormant willow propagules (cuttings or billets) in weeded and unweeded plots assessed at four different dates. Initial planting density of cuttings $\left(13.000 \mathrm{ha}^{-1}\right)$ and billets $\left(26.000 \mathrm{ha}^{-1}\right)$ are indicated by bars at May 23, 2014. Bars denoted June 30, 2014 to December 5, 2016 are mean values over clones with standard error of the means $( \pm \mathrm{SE})$. The differences within each of the four assessment dates between propagule phenology within planting system were not statistically significant $(P>0.05)$. Statistical significance $(P<$ 0.05 ) between planting system within propagule phenology is indicated by uppercase letters 
Table 3 Mixed model analysis of variance of willow aboveground biomass ( $\mathrm{t} \mathrm{DW} \mathrm{ha}{ }^{-1}$ ) in the field experiment

Willow aboveground biomass ( $\left.\mathrm{t} \mathrm{DW} \mathrm{ha}{ }^{-1}\right)$

\begin{tabular}{|c|c|c|c|c|}
\hline \multirow[b]{2}{*}{ Source of variation } & \multirow[b]{2}{*}{ Numerator $d f$} & \\
\hline & & Denominator $d f$ & $F$ value & $\operatorname{Pr}>F$ \\
\hline Weeding regime $(\mathrm{W})$ & 1 & 12 & 184.47 & $<0.0001$ \\
\hline Planting system (P) & 1 & 12 & 43.65 & $<0.0001$ \\
\hline Willow clone $(\mathrm{C})$ & 2 & 23.6 & 24.90 & $<0.0001$ \\
\hline Propagule phenology $(\mathrm{PH})$ & 1 & 34.5 & 0.39 & 0.5347 \\
\hline Assessment date (A) & 2 & 146 & 482.38 & $<0.0001$ \\
\hline $\mathrm{W} \times \mathrm{P}$ & 1 & 12 & 12.49 & 0.0041 \\
\hline $\mathrm{W} \times \mathrm{C}$ & 2 & 23.6 & 3.66 & 0.0414 \\
\hline $\mathrm{W} \times \mathrm{PH}$ & 1 & 34.5 & 0.15 & 0.7027 \\
\hline $\mathrm{W} \times \mathrm{A}$ & 2 & 146 & 252.51 & $<0.0001$ \\
\hline $\mathrm{P} \times \mathrm{C}$ & 2 & 23.6 & 0.99 & 0.3853 \\
\hline $\mathrm{P} \times \mathrm{PH}$ & 1 & 34.5 & 0.24 & 0.6239 \\
\hline $\mathrm{P} \times \mathrm{A}$ & 2 & 146 & 43.07 & $<0.0001$ \\
\hline $\mathrm{C} \times \mathrm{PH}$ & 2 & 34.5 & 2.57 & 0.0909 \\
\hline $\mathrm{C} \times \mathrm{A}$ & 4 & 146 & 15.20 & $<0.0001$ \\
\hline $\mathrm{A} \times \mathrm{PH}$ & 2 & 146 & 1.05 & 0.3512 \\
\hline $\mathrm{A} \times \mathrm{W} \times \mathrm{P}$ & 2 & 146 & 11.43 & $<0.0001$ \\
\hline $\mathrm{A} \times \mathrm{W} \times \mathrm{C}$ & 4 & 146 & 2.82 & 0.0272 \\
\hline $\mathrm{A} \times \mathrm{C} \times \mathrm{PH}$ & 4 & 146 & 1.95 & 0.1052 \\
\hline
\end{tabular}

The main effects and two-way interactions of the main effects are statistically significant at $P<0.05$. Three-way interactions were statistically significant at $P<0.20$ (only tabulated). Four-way and five-way interaction was statistically insignificant $(P>0.20)$

weeded plots from 0.69 to $19.45 \mathrm{t} \mathrm{DW} \mathrm{ha}^{-1}$ for cuttings and from 0.12 to $11.09 \mathrm{t} \mathrm{DW} \mathrm{ha}^{-1}$ for billets. In unweeded plots, aboveground biomass production increased from 0.28 to $3.93 \mathrm{t}$ DW ha ${ }^{-1}$ for cuttings and from 0.06 to $1.17 \mathrm{t} \mathrm{DW} \mathrm{ha}^{-1}$ for billets during the period March 2, 2015-December 5, 2016. Interactions between assessment date, weeding regime, and willow clone significantly affected aboveground biomass production. In weeded plots, biomass production increased from 0.42 to $16.13 \mathrm{t} \mathrm{DW} \mathrm{ha}^{-1}$ (Tora), from 0.55 to $18.66 \mathrm{t} \mathrm{DW} \mathrm{ha}^{-1}$ (Tordis), and from 0.25 to $11.07 \mathrm{t} \mathrm{DW} \mathrm{ha}^{-1}$ (Jorr) from March 2, 2015 to December 5, 2016. Aboveground biomass production increased in unweeded plots from 0.23 to $2.41 \mathrm{t} \mathrm{DW} \mathrm{ha}^{-1}$

\section{WEEDED}

\section{UNWEEDED}
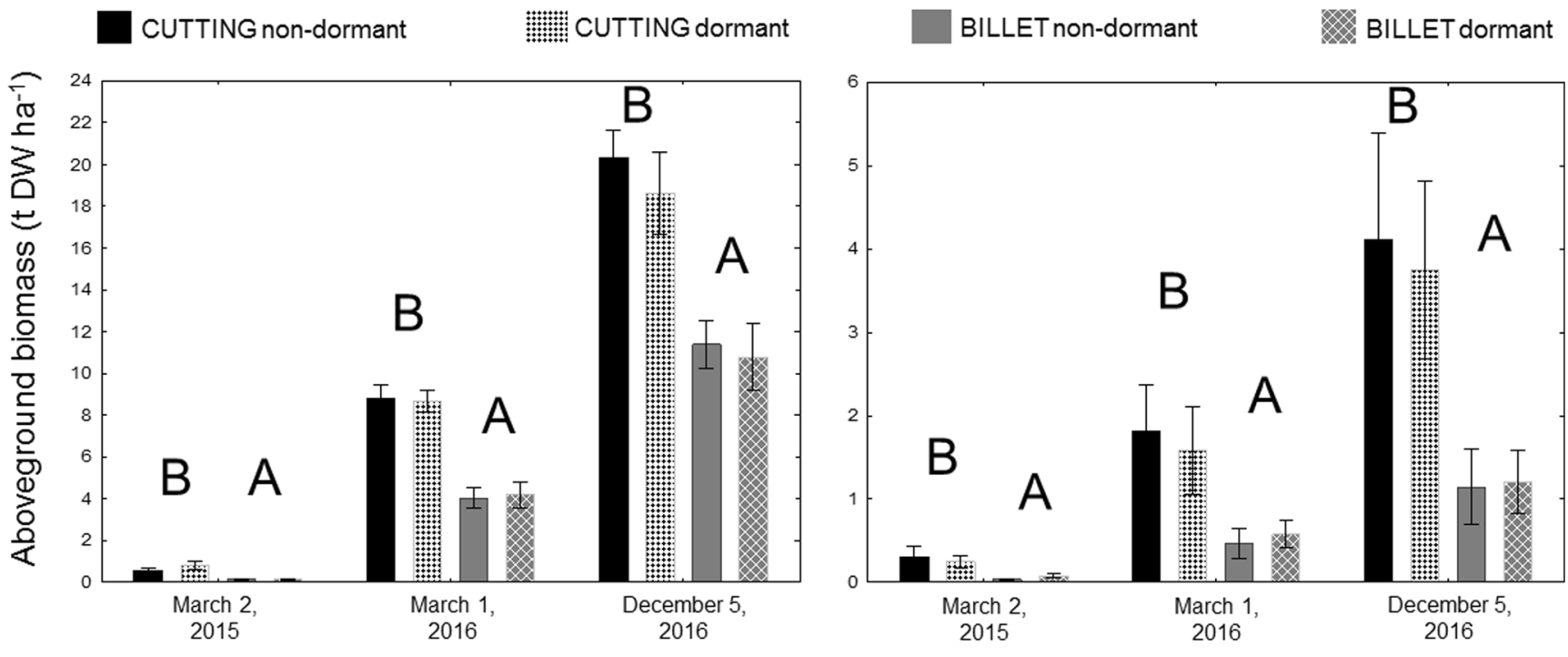

Assessment dates

Fig. 4 Willow aboveground biomass (t DW ha ${ }^{-1}$ ) from willows grown from non-dormant or dormant willow propagules (cuttings or billets) in weeded and unweeded plots assessed at three different dates. Bars represent mean values over clones with standard error of the means $( \pm \mathrm{SE})$. The differences within each of the three assessment dates between propagule phenology within planting system were not statistically significant $(P>$ $0.05)$. Statistical significance $(P<0.05)$ between planting system within propagule phenology is indicated by uppercase letters. Note the difference in scales for weeded and unweeded plots 
Table 4 Mean values of willow aboveground biomass production ( $\mathrm{t} \mathrm{DW} \mathrm{ha}{ }^{-1}$ ) produced for each treatment combination (weeding regime, planting system and assessment date)

\begin{tabular}{|c|c|c|c|c|c|c|c|}
\hline \multirow[t]{4}{*}{ Weeding regime } & \multirow[t]{4}{*}{ Planting system } & \multicolumn{6}{|c|}{ Aboveground biomass production $\left(\mathrm{t} \mathrm{DW} \mathrm{ha}{ }^{-1}\right)$} \\
\hline & & \multicolumn{6}{|c|}{ Assessment dates } \\
\hline & & \multicolumn{2}{|c|}{ March 2, 2015} & \multicolumn{2}{|c|}{ March 1, 2016} & \multicolumn{2}{|c|}{ December 5, 2016} \\
\hline & & Mean & Ratio & Mean & Ratio & Mean & Ratio \\
\hline Weeded & Cutting & $0.69 \mathrm{~b}$ & 5.52 & $8.72 b$ & 2.12 & $19.49 \mathrm{~b}$ & 1.76 \\
\hline Weeded & Billet & $0.12 \mathrm{a}$ & & $4.11 \mathrm{a}$ & & $11.09 \mathrm{a}$ & \\
\hline Unweeded & Cutting & $0.28 \mathrm{~b}$ & 4.89 & $1.69 \mathrm{~b}$ & 3.25 & $3.93 \mathrm{~b}$ & 3.34 \\
\hline Unweeded & Billet & $0.06 \mathrm{a}$ & & $0.52 \mathrm{a}$ & & $1.17 \mathrm{a}$ & \\
\hline
\end{tabular}

Statistically significant differences $(P<0.05)$ for each treatment combination are indicated by lowercase letters. Biomass ratio was calculated between cuttings and billets within each weeding regime and planting system

(Tora), from 0.20 to $4.29 \mathrm{t} \mathrm{DW} \mathrm{ha}^{-1}$ (Tordis), and from 0.07 to $0.95 \mathrm{t} \mathrm{DW} \mathrm{ha}^{-1}$ (Jorr) during the period March 2, 2015December 5, 2016.

Interactions between assessment date, willow clone, and propagule phenology significantly affected aboveground biomass production. From March 2, 2015 to December 5, 2016, aboveground biomass production increased for non-dormant propagules from 0.32 to $8.55 \mathrm{t} \mathrm{DW} \mathrm{ha}^{-1}$ (Tora), from 0.27 to 12.15 $\mathrm{t} \mathrm{DW} \mathrm{ha}^{-1}$ (Tordis), and from 0.17 to $7.04 \mathrm{t} \mathrm{DW} \mathrm{ha}^{-1}$ (Jorr). Biomass production also increased for dormant propagules from 0.32 to $9.98 \mathrm{t} \mathrm{DW} \mathrm{ha}^{-1}$ (Tora), from 0.48 to $10.81 \mathrm{t}$ DW ha ${ }^{-1}$ (Tordis), and from 0.15 to $4.99 \mathrm{t} \mathrm{DW} \mathrm{ha}^{-1}$ (Jorr) from March 2, 2015 to December 5, 2016.

\section{Discussion}

In this study, we examined the effects of propagule phenology (freshly harvested versus cold-stored) and planting system (vertical versus horizontal planting) on growth performance of willow under field conditions. Hypotheses presented in the study were grounded on the assumption that (i) non-dormant propagules will have higher activity of carbohydrate and hormone reserves than dormant propagules and (ii) the amount of carbohydrate and hormone reserves will be larger in cuttings than in billets. We postulated that these two factors, in combination with weeding regime and willow clone, will affect willow sprouting which in turn will be reflected in survival and aboveground biomass production.

Our first hypothesis, that sprouting will (a) be higher for non-dormant propagules compared with dormant ones, (b) will be higher for cuttings than billets, and (c) will be clone-dependent, was partly supported by the results. In this study, significantly more non-dormant $(74 \%)$ propagules had sprouted compared with dormant (58\%) propagules. A plausible explanation is that phenology encompasses predominantly the amount and activity of carbohydrate and hormone reserves available for willow growth. It is however difficult to disentangle which of them had preeminent impact on the willow sprouting in this study. However, depletion of carbohydrate reserves due to overwinter cold storage and storage before planting [23, 24] was probably minimized (Nils-Erik Nordh, personal communication). The period of cold storage of material used for production of dormant propagules in this study was relatively short (71 days; March 3, 2014 to May 13, 2014). Planting of both non-dormant and dormant propagules was performed maximum 4 days after their production (see Section 2 for details). Non-dormant and dormant propagules were planted early in spring, and therefore no or only minor differences in the amount of carbohydrate reserves were expected. Instead, we infer that willow sprouting was probably predominantly affected by the differences in the activity and amount of hormone reserves. Non-dormant propagules were produced from actively growing material freshly harvested from the field. In contrast, dormant cold-stored material was used to produce dormant propagules. Our assumption is supported by the results presented by Welc et al. [6] who suggested that the amount and activity of hormone rather than carbohydrate reserves was responsible for higher sprouting of non-dormant than dormant cuttings planted early in the season.

The low number of sprouted billets $(42 \%)$ compared with cuttings $(84 \%)$ seemed to be associated with drought rather than any of experimental factors tested in this study. The first month after willow planting was characterized by low precipitation, and the field experiment was established on clayey soil with relatively low permeability [25]. Probably, less moisture was available for billets planted $3 \mathrm{~cm}$ below the ground level than for cuttings having access to moisture both at the soil surface (during and immediately after precipitation) and also deeper in the soil (moisture retained in soil later after precipitation). This would be in agreement with previous studies reporting higher risk of drying out and subsequent lower 
survival of willows grown from billets than grown from cuttings [7].

Sprouting was not affected by planting system. However, when this factor was analyzed together with either assessment date or assessment date and propagule phenology, sprouting was significantly affected. The differences in sprouting were recorded between cuttings but not between billets in this study. One explanation for this observation may be that planting system comprises both propagule length (longer cuttings and shorter billets) and planting orientation (vertical versus horizontal). If sprouting will be dependent on propagule length, the differences in sprouting for both cuttings and billets (not only cuttings, as observed in this study) should be expected. Probably, the differences between non-dormant and dormant cuttings but not non-dormant and dormant billets in our study may be due to (i) the differences in hormonal activities of willow propagules when planting orientation is modified and (ii) limitations of sprouting assessment method. The amount and activity of hormone reserves change in horizontally planted billets compared with vertically planted cuttings, and the initial effect of billet phenology on willow sprouting was presumably overruled by hormonal changes triggered by planting orientation. Evidence for a strong hormonal reaction of buds to change in their orientation to gravity has been found by Worrall and Little [26], although in other species than willow (i.e., balsam fir).

Billets planted below the ground level were recorded as sprouted when the first leaves started to emerge and protrude above the soil surface. Consequently, even if minor differences in sprouting between non-dormant and dormant billets existed, they remained uncaptured by the method of sprouting assessment used in this study.

Willow survival was significantly affected by weeding regime and planting system but not by propagule phenology or willow clone. Consequently, the second hypothesis (i.e., survival will be dependent on propagule phenology and planting system) was only partially supported. Reduced survival of billets (39\% of initially planted billets) compared with cuttings ( $93 \%$ of initially planted cuttings) observed in this study complies with results of other studies where similar trends were observed. Edelfeldt et al. [8] postulated that propagule length, planting depth but also apical dominance possibly present in the horizontally planted propagules, needs to be considered as factors affecting willow survival. McCracken et al. [7] stated that compared with cuttings, billets are more susceptible to drying. Insufficient precipitation at the stage of billet planting may therefore significantly reduce their survival and subsequent performance. Furthermore, weeding regime may have a preeminent impact on survival of billets as it had on cuttings [27]. Interaction between planting system and assessment date significantly affected willow survival but only in unweeded plots (Fig. 3). This may be explained by the fact that weed cover started to develop during first growing season (March 2,
2015) and reached maximum cover in the second (March 1, 2016) growing season [28]. This may explain why willow survival was affected only in unweeded plots in the second and third growing season but not in the beginning of the first growing season.

Our results showed that the survival of plants originating from cuttings did not change significantly from planting on May 2014 to December 5, 2016, irrespectively from weeding regime. In contrast, survival of plants originating from billets seemed to decrease exponentially over time (especially in the unweeded plots). It may imply that planting system with cuttings may still be regarded as less sensitive to failures at establishment phase (also when including, e.g., impact of browsing, drought) than planting system with billets.

Aboveground biomass production was affected by weeding regime, planting system, and willow clone, but not by propagule phenology, and was higher for (i) willows grown from cuttings than from billets, (ii) willow grown in weeded than in unweeded plots, and it was also (iii) clone-dependent. These results partly support the hypothesis that aboveground biomass production over time will depend on propagule phenology and planting system and will vary between weeding regimes and willow clones.

Impact of weeding regime on aboveground biomass production persisted during all growing seasons investigated in this study. Also, it was an important factor affecting aboveground biomass production in combination with other experimental factors (i.e., weeding regime $\times$ planting system, weeding regime $\times$ willow clone, weeding regime $\times$ assessment date, assessment date $\times$ weeding regime $\times$ planting system, assessment date $\times$ weeding regime $\times$ willow clone). Willows grown in weeded plots produced approximately $15.29 \mathrm{t} \mathrm{DW} \mathrm{ha}^{-1}$ biomass compared with willows grown in unweeded plots (2.55 t DW ha ${ }^{-1}$ ) (Table 4). These observations are in accordance with results presented by Albertsson et al. [27]. Having low weed tolerance and weed suppressive ability [6], and grown at lower density compared with weeds, willows have negligible chances to outcompete weeds in competition for light [29]. Therefore, an effective weed control is crucial at the stage of willow establishment and early growth [1].

Impact of planting system on aboveground biomass production persisted over the three growing seasons investigated in this study. Moreover, planting system affected aboveground biomass production in combination with other experimental factors (i.e., weeding regime $\times$ planting system, planting system $\times$ assessment date, assessment date $\times$ weeding regime $\times$ planting system). Cuttings produced approximately $11.71 \mathrm{t}$ DW ha ${ }^{-1}$ biomass, and billets produced approximately $6.13 \mathrm{t}$ DW ha ${ }^{-1}$ biomass. The results might be explained by higher sprouting (Fig. 2) and higher survival (Fig. 3) of cuttings than of billets. This is in line with results presented by McCracken et al. [7]. They showed that mortality of billets (planting 
density $26.000 \mathrm{ha}^{-1}$ ) due to drying accounted for approximately $17 \%$ lower aboveground biomass production compared with cuttings (planting density $15.000 \mathrm{ha}^{-1}$ ) grown over two harvest cycles (6 years) in the field experiment in Ireland. Larsen et al. [9] observed that billets produced less aboveground biomass than cuttings, but that fertilization regime rather than willow mortality over time caused the differences in biomass production between the two planting systems in this particular study. The reduction in biomass production with $35 \%$ for planting system with billets (planting density $35.000 \mathrm{~h}^{-1}$ ) compared with cuttings (planting density $20.000 \mathrm{ha}^{-1}$ ) was observed during the first but not during the second harvest cycle. This suggests that a convergence in willow biomass production may appear as the growing seasons proceed. Such convergence seems also to appear from the results in this study, as the relative difference in aboveground biomass produced from cuttings and billets became smaller over time in both weeded and unweeded plots (Table 4).

Aboveground biomass production from cuttings under the conditions of this study (fertilization after first growing season) was comparable with other studies performed in the neighboring areas of Uppsala. Approximately $6.0 \mathrm{t} \mathrm{DW} \mathrm{ha}^{-1}$ (S. viminalis, clone 77683; stand distant approximately $50 \mathrm{~m}$ from the experimental field at Ultuna, Uppsala) [30] and $7.0 \mathrm{t}$ DW ha ${ }^{-1}$ (different willow clones; stand at Pustnäs, approximately $5 \mathrm{~km}$ from the experimental field at Ultuna, Uppsala) [31] were produced after first 3-year cutting cycle. An increase in biomass production could be obtained by regular fertilization [31].

Impact of willow clone on aboveground biomass production persisted during all growing seasons. Also, willow clone was affecting aboveground biomass production in combination with other experimental factors (i.e., weeding regime $\times$ willow clone, willow clone $\times$ assessment date, assessment date $\times$ weeding regime $\times$ willow clone, assessment date $\times$ willow clone $\times$ propagule phenology). The highest biomass production was recorded for willow clone Tordis (11.48 t DW $\mathrm{ha}^{-1}$ ), followed by Tora (9.27 $\mathrm{t} \mathrm{DW} \mathrm{ha}^{-1}$ ) and Jorr (6.01 t DW $\mathrm{ha}^{-1}$ ). Willow clone Tordis is regarded as less susceptible to drought than the other two willow clones and could probably better tolerate dry conditions during the establishment phase. Also, breeding techniques used to obtain Tordis (released on the market in 2000) and Tora or Jorr (released in 1996) were probably different (genetic additive variance or dominance variance in plant breeding) thus willow clones differed in productivity and performance [14]. Moreover, evidence exist that biomass production is significantly affected not only by environmental conditions [32] but also by inherent characters of willow species/clone such as e.g., bud burst. Focusing on genetics of quantitative characters in breeding of Salix, Rönnberg-Wästljung [33] confirmed a strong negative genetic correlation between willow biomass and days to bud burst, indicating the importance of early bud burst for production of biomass in willow SRC.

Propagule phenology did not affect aboveground biomass production under the conditions of this study. This is probably due to the fact that the amount of carbohydrate and hormone reserves available in non-dormant or dormant propagules (discussed above) had no subsequent impact on production of aboveground biomass. This implies that willow SRC may be established from non-dormant propagules. Thus, costs of willow SRC establishment related to propagules cold storage may be avoided. However, implementation of planting system with non-dormant propagules in practice requires that (i) harvesting of non-dormant shoots needs to be followed by planting without delay and (ii) planting need to be performed early in spring. These factors affect planning and feasibility of field work that need to be addressed by both commercial and individual willow growers.

\section{Conclusions}

We conclude that, under the conditions of this study, (i) planting with cold-stored and freshly harvested willow cuttings and billets was successful and therefore cold storage could be potentially avoided and replaced with planting of freshly harvested cuttings in early spring; (ii) in terms of measured growth performance parameters, willows grown from cuttings performed better than grown from billets; and (iii) weed competition strongly reduced willow survival and aboveground biomass production and therefore efficient weed control should be performed at the early stage of willow growth and establishment in order to maximize production of aboveground biomass in willow SRC.

Acknowledgments The authors thank the Swedish Energy Agency (grant no. 35237-1) for funding this research, Ewa Magnuski, Nils-Erik Nordh, Richard Childs, Maria, David and Erik Bergkvist, Inés Prieto Ruiz and Varwi Jacob Tavaziva for technical assistance, and Johannes Forkman for valuable pieces of advice on statistical analyses.

Open Access This article is distributed under the terms of the Creative Commons Attribution 4.0 International License (http:// creativecommons.org/licenses/by/4.0/), which permits unrestricted use, distribution, and reproduction in any medium, provided you give appropriate credit to the original author(s) and the source, provide a link to the Creative Commons license, and indicate if changes were made.

\section{References}

1. Hollsten R, Arkelöv O, Ingelman G (2012) Handbok för Salixodlare [Handbook for willow-growers]. Jordbruksverket (Swedish Board of Agriculture), Jönköping, Sweden. http:// www2.jordbruksverket.se/webdav/files/SJV/trycksaker/. Accessed 17.01.2017 
2. Gustafsson J, Larsson S, Nordh NE (2007) Manual för salixodlare [Manual for salix growers]. http://www.bioenergiportalen.se/ attachments/42/406.pdf. Accessed 17.01.2017

3. Verwijst T, Lundkvist A, Edelfeldt S, Albertsson J (2013) Development of sustainable willow short rotation forestry in northern Europe. In: Matovic MD (ed) Biomass now-sustainable growth and use. InTech, Rijeka, Croatia, pp 479-502

4. Caslin B, Larsson S, McCracken A (2010) Short rotation coppice willow - best practice guidelines. Teagasc, Crops Research Centre, Oak Park, Carlow, Ireland. http://www.seai/Renewables/ Bioenergy/Willow_Best_Practice_Guide_2010.pdf. Accessed 17. 01.2017

5. Rosenqvist H (2017) Kalkyler för energigrödor: fastbränsle, biogas, spannmål och raps [Calculations for energy crops: solid fuel, biogas, cereals and rapeseed]. Jordbruksverket. http://webbutiken. jordbruksverket.se/sv/artiklar/ovr403.html. Accessed 12.09.2017

6. Welc M, Lundkvist A, Verwijst T (2017) Effects of cutting phenology (non-dormant versus dormant) on early growth performance of three willow clones grown under different weed treatments and planting dates. BioEnergy Research 10:1094-1104. https://doi. org/10.1007/s12155-017-9871-2

7. McCracken AR, Moore JP, Walsh LRE, Lynch M (2010) Effect of planting vertical/horizontal willow (Salix spp.) cuttings on establishment and yield. Biomass Bioenergy 34(12):1764-1769. https:// doi.org/10.1016/j.biombioe.2010.07.008

8. Edelfeldt S, Lundkvist A, Forkman J, Verwijst T (2015) Effects of cutting length, orientation and planting depth on early willow shoot establishment. BioEnergy Research 8(2):796-806. https://doi.org/ 10.1007/s12155-014-9560-3

9. Larsen SU, Jørgensen U, Kjeldsen JB, Lærke PE (2014) Long-term yield effects of establishment method and weed control in willow for short rotation coppice (SRC). Biomass Bioenergy 71:266-274. https://doi.org/10.1016/j.biombioe.2014.10.001

10. Gro V, Culshaw D (2003) How is life if you try to live from developing SRC in Denmark? Experiences, results and recommendations. DIAS Report, Plant Production 86:29-34

11. Olsson MT, Samils B (1984) Site characterisation an energy forest production. Report no 48, Department of Forest Soils, SLU, Uppsala, Sweden

12. Anonymous (2016) Ultuna climate station. SLU, Uppsala, Sweden. http://grodden.evp.slu.se/slu_klimat/slu_files/dygn.html. Accessed 20.06.2016

13. Weih M, Nordh N-E (2005) Ekologisk karakterisering av Salix kloner med hänsyn till vatten och näringstillgång. Slutrapport Institutionen för Växtproduktionsekologi, SLU, Uppsala, Sweden

14. Caslin B, Finnan J, McCracken A (2012) Willow varietal identification guide. Teagasc, Oak Park, Carlow, Ireland

15. Verwijst T, Lundkvist A, Edelfeldt S, Forkman J, Nordh N-E (2012) Effects of clone and cutting traits on shoot emergence and early growth of willow. Biomass Bioenergy 37(0):257-264. https://doi. org/10.1016/j.biombioe.2011.12.004

16. Agné H (1991) Gödsling till Salixodling [Fertilisation of Salix]. Växtpressen Hydro Supra AB (numera: Hydro Agri AB)
17. Verwijst T, Telenius B (1999) Biomass estimation procedures in short rotation forestry. For Ecol Manag 121(1-2):137-146. https://doi.org/10.1016/S0378-1127(98)00562-3

18. Littell RC, Milliken GA, Stroup WW, Wolfinger RD, Schabenberger O (2006) SAS for mixed models, 2nd edn. SAS Institute Inc., Cary, North Carolina, USA

19. McDonald JH (2014) Handbook of biological statistics, 3rd edn. Sparky House Publishing, Baltimore, Maryland, USA

20. Bithell SL, Butler RC, Harrow S, McKay A, Cromey MG (2011) Susceptibility to take-all of cereal and grass species, and their effects on pathogen inoculum. Ann Appl Biol 159:252-266

21. Piepho HP, Büchse A, Richter C (2004) A mixed modelling approach for randomized experiments with repeated measures. $\mathrm{J}$ Agron Crop Sci 190(4):230-247. https://doi.org/10.1111/j.1439037X.2004.00097.x

22. Frogillo E (2004) Evaluating statistical interactions. StatNews 64 Cornell University Cornell Statistical Consulting Unit

23. Volk TA, Ballard B, Robison DJ, Abrahamson LP (2004) Effect of cutting storage conditions during planting operations on the survival and biomass production of four willow (Salix L.) clones. New For 28(1):63-78. https://doi.org/10.1023/B:NEFO.0000031334.86593. $4 \mathrm{e}$

24. Tilley D, Loren SJ (2012) Effects of long-term refrigerated storage on hardwood willow cuttings. Technical note USDA - Natural Resources Conservation Service Boise, Idaho

25. Brady NC, Weil RR (2008) The nature and properties of soils, 14th edn. Pearson Education Limited, Edinburgh, United Kingdom

26. Worrall J, Little C (1986) An effect of gravity on bud-burst in balsam fir. Tree Physiol 1(1):47-52

27. Albertsson J, Hansson D, Bertholdsson NO, Ahman I (2014) Siterelated set-back by weeds on the establishment of 12 biomass willow clones. Weed Res 54(4):398-407. https://doi.org/10.1111/wre. 12086

28. Welc M (2017) Growth performance, population dynamics and floristic diversity in willow cultivations. Department of Crop Production Ecology. Doctoral thesis. Acta Universitatis Agriculturae Sueciae 2017: 111, SLU, Uppsala, Sweden

29. Sage RB (1999) Weed competition in willow coppice crops: the cause and extent of yield losses. Weed Res 39(5):399-411. https:// doi.org/10.1046/j.1365-3180.1999.00154.x

30. Sannervik AN, Eckersten H, Verwijst T, Kowalik P, Nordh NE (2006) Simulation of willow productivity based on radiation use efficiency, shoot mortality and shoot age. Eur J Agron 24(2):156164. https://doi.org/10.1016/j.eja.2005.07.007

31. Weih M, Nordh NE (2005) Determinants of biomass production in hybrid willows and prediction of field performance from pot studies. Tree Physiol 25(9):1197-1206

32. Rönnberg-Wästljung AC, Gullberg U, Nilsson C (1994) Genetic parameters of growth characters in Salix viminalis grown in Sweden. Can J For Res 24(9):1960-1969

33. Rönnberg-Wästljung AC (1996) Breeding in Salix. Genetics of quantitative characters. Department of Plant Breeding, Uppsala Genetic Centrum. Doctoral thesis 19961607587. SLU, Uppsala, Sweden 